よって結晶子の大きさを計算して，打の括のの系のコークス化に ともなう基本構造の変化を求めた。既報の諸実験を含めて，その 変化過程は相当複雑で，とくにコークス强度の低い場合には結晶 子の生長過程が不規則である。この不規則さがコークス化中にひ びの原因となると推定される。適当な配合によって, 結晶子は次 第に素直に生長する過程へ近つく。実用配合に近い多炭種の配合
の場合を同じ方法で実験しても，結晶子の生長はきわめて順調で あることが認められた。

（昭和 30 年 4 月，日化第 8 年会講演）

本報の実験を実施する間，富士製鉄株式会社厸畑製鉄所より種 々の援助をえた。ここに記して感謝の意を表わす。

\title{
連結反応および交換連結反応に関する研究†
}

(昭和 31 年 5 月 23 日受理)

\section{小田良平・谷本重夫・野村元昭・西村恒彥・京 加祐門*}

前報1)においてアミンとアルコールとのホルムアルデヒドによ る連結化合物技よびアルコールのクロルメチルェーテルとフェニ ルイソシアナートとの交換連結反応について報告した。さらに前 報に類した研究を行ったので報告する。

（1） アミンとアルコールのホルムアルデヒドによる連結化合 物とスチレンとの反応 Dermer') はメチラールすなわち2 分子 のメタノールがホルムアルデヒドによって連結された化合物が $\mathrm{BF}_{3}$ 触媒によって次のように $\alpha$-オレフィンと反応することを発 表している。これは一種の交換連結反応である。

$$
\begin{aligned}
& \mathrm{CH}_{3} \mathrm{OCH}_{2} \mathrm{OCH}_{3}+\mathrm{R}-\mathrm{CH}=\mathrm{CH}_{2} \stackrel{\mathrm{BF}_{3}}{\longrightarrow} \mathrm{R}-\mathrm{CH}-\mathrm{CH}_{2}-\mathrm{CH}_{2} \mathrm{OCH}_{3} \text { (主) } \\
& \mathrm{OCH}_{3} \\
& \text { R-CH- } \mathrm{CH}_{2}-\mathrm{OCH}_{3} \\
& \mathrm{CH}_{2} \mathrm{OCH}_{3}
\end{aligned}
$$

したがって著者らはアミンとアルコールとがホルムアルデヒド によって連結された化合物も $\alpha$ 一オレフィン（スチレンを選んだ） と次のように反灾するであろうと考え，予期ど扣りの結果をえた。

$$
\begin{aligned}
& \stackrel{\mathrm{C}_{2} \mathrm{H}_{5}}{\mathrm{C}_{2} \cdot \mathrm{H}_{5}}>\mathrm{N}-\mathrm{CH}_{2}-\mathrm{OC}_{4} \mathrm{H}_{0}(n)+\mathrm{C}_{6} \mathrm{H}_{5} \mathrm{CH}=\mathrm{CH}_{2} \stackrel{\mathrm{BF}_{3}}{\longrightarrow} \\
& \stackrel{\mathrm{C}_{6} \mathrm{H}_{5}-\mathrm{CH}-\mathrm{CH}_{2}-\mathrm{CH}_{2} \mathrm{~N}}{\mathrm{OC}_{4} \mathrm{H}_{3}} \underset{\mathrm{C}_{2} \mathrm{H}_{5}}{\mathrm{C}_{?} \mathrm{H}_{5}}
\end{aligned}
$$

ただしブトキシ基は反言後の操作中容易に加水分解されるよう で，実際反応生成物として碓認したものはこれがヒドロキシル基 となったものである。

（2）アミンとアルコールとのホルムアルデヒドによる連結化 合物とエチレンオキシドとの反応 Dermer ${ }^{3)}$ はメチラールが $\mathrm{BF}_{3}$ 触媒によってエチレンオキシドと次のように反応することを発表 している。これも一種の交換連結反応である。

$\mathrm{CH}_{3} \mathrm{OCH}_{2} \mathrm{OCH}_{3}+\mathrm{CH}_{2} \mathrm{O}^{\prime} \mathrm{CH}_{3} \stackrel{\mathrm{BF}_{3}}{\rightarrow} \mathrm{CH}_{3} \mathrm{OCH}_{2}-\mathrm{OCH}_{2} \mathrm{CH}_{2} \mathrm{OCH}_{3}$

$$
\stackrel{n\left(\mathrm{CH}_{5}-\mathrm{CH}_{2}^{\prime}\right)}{\stackrel{\mathrm{O}^{\prime}}{\longrightarrow}} \mathrm{CH}_{3} \mathrm{OCH}_{2}-\left(\mathrm{OCH}_{2} \mathrm{CH}_{2}\right)_{n} \mathrm{OCH}_{2} \mathrm{CH}_{2} \mathrm{OCH}_{3}
$$

2 段目の反応はイオン的なテロメリゼーションと見ることができ る。

†本報告を「連結反応および交換連結反応に関する研究（第 4 報)」とする.

* 京都大学工学部工業化学教室：京都市左京区.

1) 野村, 西村, 小田, 工化 59, 384 (1956).

2) O.C. Dermer, J. Am. Chem. Soc. 74, 4595 (1952).

3) O.C. Dermer, ibid. 76, 912 (1954).
著者らは，したがってアミンとアルコールとがホルムアルデヒ ドによって連結された化合物もエチレンオキシドと次のよ5に交 換連絬反応を起寸であろらと予期し，そのとおりの絬果をえた。

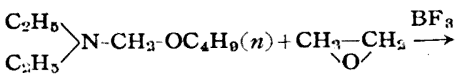

$$
\begin{aligned}
& \mathrm{C}_{2} \mathrm{H}_{5} \mathrm{H}_{5}>\mathrm{N}-\mathrm{CH}_{2}-\mathrm{OCH}_{2} \mathrm{CH}_{2} \mathrm{OC}_{4} \mathrm{H}_{8}
\end{aligned}
$$

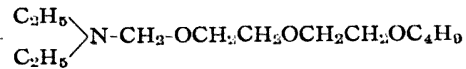

（3） アミンとアルコールとのホルムアルデヒドによる連結化 合物とケテンとの反応 ホルマールとケテンとが次のごとく反応 することはすでに知られている゙)。

$$
\mathrm{R}-\mathrm{O}-\mathrm{CH}_{3}-\mathrm{OR}+\mathrm{CH}_{2}=\mathrm{C}=\mathrm{O} \stackrel{\text { 酸性触媒 }}{\longrightarrow} \mathrm{ROCH}_{2}-\mathrm{CH}_{2}-\mathrm{C}<\mathrm{OR}
$$

そこでアミンとアルコールとのホルムアルデヒドによる速結化 合物に打いても同様な反応が起るであるうと予期して研究したと ころ, 実際の反応生成物はカルボン酸エステルは少量で, 主とし てカルボン酸アミドであった。

$$
\begin{aligned}
& { }_{\mathrm{R}}^{\mathrm{R}}>\mathrm{N}-\mathrm{CH}_{2}-\mathrm{OR}^{\prime}+\mathrm{CH}_{2}=\mathrm{C}=\mathrm{O} \rightarrow{ }_{\mathrm{R}}^{\mathrm{R}}>\mathrm{N}-\mathrm{CH}_{2}-\mathrm{CH}_{2}-\mathrm{C}<\mathrm{OR}^{\prime} \\
& \rightarrow{ }_{\mathrm{F}}^{\mathrm{R}}>\mathrm{N}-\mathrm{CH}_{3} \cdot \mathrm{CH}_{2}-\mathrm{C} \ll_{\mathrm{N}}^{\mathrm{O}}<_{\mathrm{R}}^{\mathrm{R}}
\end{aligned}
$$

${ }_{\mathrm{R}}^{\mathrm{R}}>\mathrm{NH}$ としてはジェチルアミン，モルホリン，ピペリジンを， $\mathrm{R}^{\prime} \mathrm{OH}$ としてはエタノール，nーブタノールを用いた。

な执メチレンビスアミンとケテンに拈いても次のごとき交換連 結反応が起ることを確かめた。

$$
{ }_{\mathrm{R}}^{\mathrm{R}}>\mathrm{N}-\mathrm{CH}_{2}-\mathrm{N}\left\langle{ }_{\mathrm{R}}^{\mathrm{R}}+\mathrm{CH}_{2}=\mathrm{C}=\mathrm{O} \rightarrow{ }_{\mathrm{R}}^{\mathrm{R}}>\mathrm{N}-\mathrm{CH}_{2}-\mathrm{CH}_{2}-\mathrm{C}<{ }_{\mathrm{N}}^{\mathrm{O}}<_{\mathrm{R}}^{\mathrm{R}}\right.
$$

（4）安息香酸アミドと重亜硫酸ソーダとのホルムアルデヒト による連結化合物と安息香酸アミド,フタルイミド，カルパゾー ルとの間に次に示すような交換連結反応の起ることを確かめた。

$\mathrm{C}_{6} \mathrm{H}_{5} \mathrm{CONH}-\mathrm{CH}_{2} \mathrm{SO}_{3} \mathrm{Na}+\mathrm{C}_{6} \mathrm{H}_{5} \mathrm{CONH}_{2}$ $\stackrel{\mathrm{C}_{3} \mathrm{H}_{5} \mathrm{ONa}}{\longrightarrow} \mathrm{C}_{6} \mathrm{H}_{5} \mathrm{CONH}-\mathrm{CH}_{2}-\mathrm{NHCOC}_{8} \mathrm{H}_{6}$

$\mathrm{C}_{3} \mathrm{H}_{5} \mathrm{CONH}-\mathrm{CH}_{2} \mathrm{SO}_{3} \mathrm{Na}+\overbrace{\mathrm{CO}^{\prime}}^{\mathrm{CO}_{\searrow}^{\prime}}$

$$
\stackrel{\mathrm{C}_{3} \mathrm{H}_{5} \mathrm{ONa}}{\longrightarrow} \mathrm{C}_{8} \mathrm{H}_{5} \mathrm{CONH}-\mathrm{CH}_{2}-\mathrm{N}
$$

4) F. Sorm, Chem. Abst. 49, 1751 (1955). 


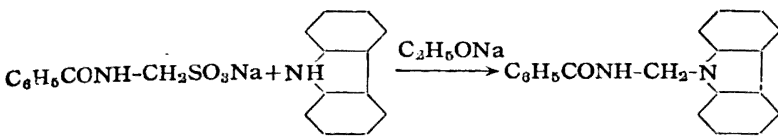

実 験 の 部

\section{（1） アミンとアルコールのホルムアルデヒドによる連結化合} 物とスチレンとの反応

試料に用いたジェチルアミノメチルーブチルエーテル $\left(\begin{array}{l}\mathrm{C}_{2} \mathrm{H}_{5} \\ \mathrm{C}_{2} \mathrm{H}_{5}\end{array}\right)_{N}$ $\left.-\mathrm{CH}_{2}-\mathrm{O}-\mathrm{C}_{4} \mathrm{H}_{8}\right)$ はすでに前報にす述べたように Stewart $\left.{ }^{5}\right)$ の方法 で合成し, bp $71 \sim 72^{\circ} \mathrm{C} / 18 \mathrm{mmHg}$, 中和当量 $=157.5$ (計算值159) のものを用いた。気密カキマゼ機, 温度計, ガス吹込管および塩 化カルシウム管をつけた四つロフラスコ中でジェチルアミノメチ ルーブチルエーテルとスチレンとを $2: 1$ モル比に混ぜ, 寒剤で十 分泠却し, 激しくかきまぜながら $\mathrm{BF}_{3}$ ガスを導入し，ほほ飽和 させる。この間激しく発熱するが, 温度が $10^{\circ} \mathrm{C}$ 以上にならぬよ 5 K $\mathrm{BF}_{3}$ の欣込み速度を加減する。 $\mathrm{BF}_{3}$ が飽和以上になると塩 化石灰管を通って外部に白煙が現われるので検知できる。反応液 は淡黄色, 粘稠となり末反応スチレンが上層に分離して来る。 $\mathrm{BF}_{3}$ はジェチルアミノメチルーブチルエーテル $1 \mathrm{~mol}$ に対しほぼ $2 \mathrm{~mol}$ 吸収されることがその吸収量からわかる。 $\mathrm{BF}_{3}$ が飽和後室 温で約 30 時間かきまぜることを続けると豆腐状の軟い半固体と なる。これを $30 \% \mathrm{NaOH}$ 液中に冷却下に徐々に加え，油層を エーテル抽出し，エーテル抽出液をボウ硝で乾燥後分留する。絬 果をまとめて第 1 表に示す。

\begin{tabular}{|c|c|c|c|c|c|}
\hline \multirow{3}{*}{$\frac{\mathrm{Et}_{2} \mathrm{~N}-\mathrm{CH}_{3}-\mathrm{OBu}}{(\mathrm{g})}$} & \multicolumn{2}{|c|}{ 第 } & \multicolumn{2}{|l|}{ 表 } & \multirow[b]{2}{*}{$\begin{array}{l}\text { 蒸留残留物 } \\
(\mathrm{g})\end{array}$} \\
\hline & $\begin{array}{c}\text { スチレン } \\
(\mathrm{g})\end{array}$ & $\underset{(\mathrm{g})}{\mathrm{BF}_{3}}$ & $\underset{\mathrm{CH}_{2} \mathrm{CH}_{2} \mathrm{NEt}_{2} \mathrm{H}_{5}-\mathrm{CHOH}-}{-}$ & & \\
\hline & 10 & 5 & $60 \sim 80^{\circ} \mathrm{C} / 5 \mathrm{mmHg}$ & 1 & - \\
\hline 32 & 10 & 25 & $89 \sim 94^{\circ} \mathrm{C} / 6 \mathrm{mmHg}$ & 5 & 5 \\
\hline 48 & 16 & 34 & $73 \sim 79^{\circ} \mathrm{C} / 4 \mathrm{mmHg}$ & - & - \\
\hline 48 & 16 & 30 & $60 \sim 90^{\circ} \mathrm{C} / 8 \mathrm{mmHg}$ & 5 & 13 \\
\hline 64 & 21 & 48 & $60 \sim 90^{\circ} \mathrm{C} / 7.5 \mathrm{mmHg}$ & 12 & 17 \\
\hline
\end{tabular}

留出油を 2 回精留して $89 \sim 90^{\circ} \mathrm{C} / 7.5 \mathrm{mmHg}$ のものを採取し, これを塩酸塩として再結晶すると $\mathrm{mp}=151 \sim 152^{\circ} \mathrm{C}$ でその分析 值は次のようである。カッコ内は $\mathrm{C}_{13} \mathrm{H}_{22} \mathrm{NOCl}$ としての計算值で ある。

C $64.85 \%$ (64.07), H 8.90\% (9.03), N 5.71\% (5.73)

またメチアイオダイドとしての分析值は次のよ5である。

C $47.85 \%$ (48.14), H 6.63\% (6.87), N 4.05\% (4.01)

（2）アミンとアルコールとのホルムアルデヒドによる連結化 合物とエチレンオキシドとの反応

夜状エチレンオキシドを用い前項のスチレンの場合とほぼ同様 に行った。ただしかきまぜ反応時間を8時間とする。かつ反応生 成物は半固体状にはならない。たとえばジェチルアミノメチルー ブチルエーテル $64 \mathrm{~g}$ とェチレンオキシド $10 \mathrm{~g}$ との混合物に $\mathrm{BF}_{3}$ 䄪 $40 \mathrm{~g}$ を吸収させた反応液からエーテル抽出して, 80〜 $140^{\circ} \mathrm{C} / 6 \sim 8 \mathrm{mmHg}$ の留分を捕集し, これをウィドマー精留塔を 用い精留して次の二つの留分をえた。

(a) $82 \sim 84^{\circ} \mathrm{C} / 8 \mathrm{mmHg}(4 \mathrm{~g})$ ，再精留 $76.5 \sim 77^{\circ} \mathrm{C} / 6 \mathrm{mmHg}$ 。 これをさらに金属 Naで混入しているエチレングリコールと思わ れる物質を除き，分析すると次のよ5で，カッコ内に示した $\mathrm{Et}_{2}$. $\mathrm{NCH}_{2} \mathrm{OCH}_{2} \mathrm{CH}_{2} \mathrm{OBu}$ としての計算とほほ一致する。

C $64.63 \%(65.02), \mathrm{H} 12.22 \%(12.31), \mathrm{N} 6.40 \%(6.90)$

5) T. D. Stewart, '. Am. Chem. Soc. 54, 4176 (1932). (b) $108 \sim 109^{\circ} \mathrm{C} / 6.5 \mathrm{mmHg}(2 \mathrm{~g})$, 再精留 $116^{\circ} \mathrm{C} / 6 \mathrm{mmHg}$ 。 C $62.93 \%$ (63.16) H $11.68 \%$ (11.74) N 5.97\% (5.67) カッコ内は $\mathrm{Et}_{2} \mathrm{NCH}_{2} \mathrm{OCH}_{2} \mathrm{CH}_{2} \mathrm{OCH}_{2} \mathrm{CH}_{2} \mathrm{OBu}$ としての計算値で . 中和当量は 238 (計算値 247) であり, 比較的よく一致している。

（3）アミンとアルコールとのホルムアルデヒドによる連結化 合物とケテンとの反応

用いたアミノメチルーアルキルェーテルおよびメチレンビスア ミンはすべて Stewart の方法で合成し，その特性の次のごとき ものを使用した。

\begin{tabular}{|c|c|c|c|}
\hline & \multirow{2}{*}{$\left({ }^{\circ} \mathrm{C} / \mathrm{mm}\right.$ 点 $\left._{\mathrm{H}}\right)$} & \multicolumn{2}{|c|}{ 中和当㧰 } \\
\hline & & 実 测 & 計 濞 \\
\hline$\left(\mathrm{C}_{2} \mathrm{H}_{6}\right)_{2} \mathrm{~N}-\mathrm{CH}_{2}-\mathrm{OC}_{2} \mathrm{H}_{5}$ & $131.5 \sim 132.5 / 760$ & 130.5 & 131 \\
\hline$\left(\mathrm{C}_{2} \mathrm{H}_{6}\right)_{3} \mathrm{~N}-\mathrm{CH}_{2}-\mathrm{OC}_{4} \mathrm{H}_{8}(n)$ & $71 \sim 72 / 18$ & 157.5 & 159 \\
\hline $\mathrm{N}-\mathrm{CH}_{2}-\mathrm{OC}_{4} \mathrm{H}_{\mathbf{8}}$ & $104.5 \sim 107 / 18$ & 170 & 173 \\
\hline $\mathrm{N}-\mathrm{CH}_{2}-\mathrm{OC}_{4} \mathrm{H}_{\theta}$ & $103 \sim 105 / 20$ & 166 & 171 \\
\hline$\left(\mathrm{C}_{2} \mathrm{H}_{5}\right)_{2} \mathrm{~N}-\mathrm{CH}_{2}-\mathrm{N}\left(\mathrm{C}_{2} \mathrm{H}_{5}\right)_{2}$ & $166 \sim 168 / 760$ & 78 & 79 \\
\hline O N- $\mathrm{CH}_{2}-\underbrace{\prime} ?$ & $129 \sim 132 / 12$ & 94 & 93 \\
\hline $\mathrm{N}-\mathrm{C}_{\mathrm{Hs}}-$ & $100.6 / 12$ & 90.6 & 91 \\
\hline
\end{tabular}

ケテンはアセトンの熱分解法で製造し寒剤で冷却したトラップ を通して十分アセトンを除いて反応液中に通じた。実施例を示す と次のようである。

気密カキマゼ機, 温度計, 塩化カルシウム管およびケテン吹込 管をつけた内容 $200 \mathrm{cc}$ の四つロフラスコにジェチルアミノメチ ルーエチルエーテル $0.3 \mathrm{~mol}$ と無水エーテル $70 \mathrm{cc}$ 抽よび無水塩 化亜鉛 $47 \mathrm{~g}(0.35 \mathrm{~mol})$ を入れ，寒剤で冷却，かきまぜながら $-10^{\circ} \mathrm{C}$ 以下でケテンの吹込みを始める。反応熱のために温度は 4〜 6 ${ }^{\circ} \mathrm{C}$ となる。ケテンの吹込みを 35 分つうけけと温度が降り始 め反応液が淡黄色となる。そこでケテンの吹込みを中止して，一 夜放置する。ケテンガスの吹込量はガスの貯蔵がむずかしく発生 器から直接導入したので正確には決めていない。したがって反応 熱の発生が止って温度の降り始める点を終点とした。次に反応液 を $15 \%$ アンモニア水 $220 \mathrm{cc}$ 中に加光塩化亜鉛を溶解し，油層 を分離し，水層を 3 回エーテル抽出し，油層と合し，無水ボウ硝 で乾燥後エーテルを留去し，次にウィドマー分留荅をつけて精留 し, $49 \sim 79^{\circ} \mathrm{C} / 9 \mathrm{mmHg}$ の留分 $5 \mathrm{~g}$ と $98 \sim 113^{\circ} \mathrm{C} / 7 \mathrm{mmHg}$ の留 分 $10.5 \mathrm{~g}$ とをえた。

低沸点留分を希塩酸に溶解し, 塩酸に不溶分をエーテルで抽出 除去し，水相を炭酸ソーダでアルカリ性とし，再びアミンを雄離 させ, エーテル抽出, ボウ硝で乾燥し, 再精留して $75 \sim 76^{\circ} \mathrm{C} /$ $11.5 \mathrm{mmHg}$ の留分を $2.5 \mathrm{~g}$ 光た。この沸点は $\beta$-ジェチルアミ ノプロピオン酸エチルェステルの bp $83 \sim 84^{\circ} \mathrm{C} / 12 \mathrm{mmHg}{ }^{6)}$ より やや低いが分析值はよく一致し，これをメチアイオダイドとする と $\mathrm{mp} 77 \sim 81^{\circ} \mathrm{C}$ を示し, 文献值と一致し, 分析值も一致する。 カッコ内は計算值。

メチアイオダイドの分析值

C $38.14 \%$ (38.09), H 7.25\%(7.00), N 4.07\% (4.44)

故に予期のごとく反応の起ったことがわかる。

次に高沸点留分を再蒸留すると大部分 $103 \sim 106^{\circ} \mathrm{C} / 6 \mathrm{mmHg}$ て 留出し, これは $\mathrm{N}, \mathrm{N}-$-ジェチルー $\beta$-ジェチルアミノプロピオン酸 アミド $\left[\left(\mathrm{C}_{2} \mathrm{H}_{5}\right)_{2} \mathrm{NCH}_{2} \mathrm{CH}_{2} \mathrm{CON}\left(\mathrm{C}_{2} \mathrm{H}_{5}\right)_{2}\right]$ であることを次のごと くして確認した。すなわちメチルオレンジを指示薬としてN/10-

6) Beilstein 4, 404. 


\begin{tabular}{|c|c|c|c|c|c|c|c|c|c|c|c|c|}
\hline \multirow{3}{*}{ アミノメチルーフルキルエーテル } & \multicolumn{2}{|c|}{ 低沸点生成物， } & 第 & & 2 & 表 & \multicolumn{2}{|c|}{ 高沸点生成物, } & & & & \\
\hline & \multirow[b]{2}{*}{ 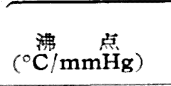 } & \multirow[b]{2}{*}{$\begin{array}{l}\text { 收率 } \\
(\%)\end{array}$} & \multicolumn{4}{|c|}{ 元秦分析 (カッコ内忙計算值) } & \multirow{2}{*}{ 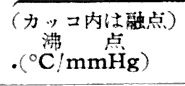 } & \multirow[b]{2}{*}{ 収率 } & \multicolumn{4}{|c|}{ 元素分析（カッコ内は計算値） } \\
\hline & & & C & $\mathrm{H}$ & $\mathrm{N}$ & 中和当最 & & & c & $\mathrm{H}$ & $\mathrm{N}$ & 中和当聂 \\
\hline$\left(\mathrm{C}_{2} \mathrm{H}_{5}\right)_{3} \mathrm{~N}-\mathrm{CH}_{2}-\mathrm{OC}_{2} \mathrm{H}_{5}$ & $75 \sim 76 / 11.5$ & 9.72 & $\begin{array}{l}62.38 \\
(62.43)\end{array}$ & $\begin{array}{l}11.13 \\
(10.98)\end{array}$ & $\begin{array}{l}7.91 \\
(8.09)\end{array}$ & $\begin{array}{l}172.6 \\
(173)\end{array}$ & $103 \sim 106 / 6.0$ & 35.2 & ピクレ. & ートとして & 分析 & $\begin{array}{l}197 \\
(200)\end{array}$ \\
\hline$\left(\mathrm{C}_{2} \mathrm{H}_{5}\right)_{2} \mathrm{~N}-\mathrm{CH}_{2}-\mathrm{OC}_{4} \mathrm{H}_{8}$ & $93.5 \sim 94.5 / 8$ & 9.95 & $\begin{array}{c}65.35 \\
(65.67)\end{array}$ & $\begin{array}{l}11.76 \\
(11.44)\end{array}$ & $\begin{array}{l}6.91 \\
(6.96)\end{array}$ & $\begin{array}{l}205.9 \\
(201)\end{array}$ & $103 \sim 105 / 6.0$ & 20.0 & ピクレ & ートとして & 分析 & - \\
\hline $\mathrm{O}^{\mathrm{N}}-\mathrm{CH}_{3}-\mathrm{OC}_{4} \mathrm{H}_{\mathrm{\theta}}$ & $117 \sim 118 / 10$ & 14.0 & $\begin{array}{l}61.67 \\
(61.40)\end{array}$ & $\begin{array}{l}9.93 \\
(9.77)\end{array}$ & $\begin{array}{l}7.26 \\
(6.51)\end{array}$ & - & $(89 \sim 93)$ & 3.5 & $\begin{array}{l}57.62 \\
(57.89)\end{array}$ & $\begin{array}{l}8.70 \\
(8.77)\end{array}$ & $\begin{array}{l}12.54 \\
(12.28)\end{array}$ & - \\
\hline$\underset{N}{N}-\mathrm{CH}_{2} \mathrm{OC}_{4} \mathrm{H}_{8}$ & $101 \sim 102 / 5.5$ & 18.8 & $\begin{array}{l}67.09 \\
(67.61)\end{array}$ & $\begin{array}{l}10.73 \\
(10.80)\end{array}$ & $\begin{array}{l}6.65 \\
(6.57)\end{array}$ & - & $(37 \sim 41)$ & 53.6 & $\begin{array}{l}69.25 \\
(69.64)\end{array}$ & $\begin{array}{l}11.18 \\
(10.71)\end{array}$ & $\begin{array}{l}12.56 \\
(12.50)\end{array}$ & - \\
\hline
\end{tabular}

$\mathrm{HCl}$ で滴定すると中和当量 197 (計算值 201) となり, 次に塩酸 と 2.5 時間還流著沸して加水分解を行ってジェチルアミンと $\beta$ ジエチルアミノプロピオン酸とをえた。ジェチルアミンは塩酸塩 として標品との混融により確かめ， $\beta$-ジェチルアミノプロピオン 酸も塩酸塩として確認した。また $\beta$-ジェチルアミノプロピオン 酸アミドを常法によりピクレートとして分析してこれを確かめた。 ピクレート分析值, カッコ内は計算值。

C $47.39 \%$ (47.55), H 6.31\% (6.29), N 16.33\% (16.32) な敃低沸点留分中の塩酸不溶の部分は bp $70 \sim 71^{\circ} \mathrm{C} / 17.5 \mathrm{~mm}$

Hg で, $\beta$ ートキシプロピオン酸エチルェスエルと思われるが， 試料が少量のため確認はできなかった。

他のアミノメチルアルキルェーテルとケテンとの反忘も大体に おいて同様に行い，いずれの場合も 2 種の生成物をえた。その一 つは $\beta$-アミノプロピオン酸エステルで他はそのアミドである。 その結果をまとめて表示すると第 2 表のようである。ただし高沸 点の酸アミド型生成物でジェチルアミン系のものは前記のように ピクレートとして確認したが，モルホリン，ピペリジンを用いた ものではそのままで再結晶で精製が可能で，そのまま元素分析し た。

次にメチレンビスアミンとケテンとの反応も汪同様の条件で 行った。ただし，塩化西鉛をメチレンビスアミン $1 \mathrm{~mol}$ に対し $2.5 \mathrm{~mol}$ の割合に使用した。またメチレンビスモルホリンの場 合，エーテル相からの生成物の収率は $6 \%$ にすぎなかったが，水 相を蒸発乾固し, アセトン抽出して蒸留し, 合計 $57 \%$ の収婆と なった。メチレンビスピペリジンの場合は水相からは汪とんど回 収物なく，またメチレンビスジェチルアミンの場合は水相はしら ベていない，ただェーテル相のみからの収率であった。これらの

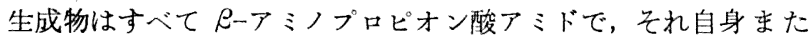
はピクレートとして前記の場合の生成物と混融によって確認し た。その結果は次のようである。 $\mathrm{R} \cong \mathrm{N}-\mathrm{CH}_{2}-\mathrm{NR}_{\mathrm{2}}{ }_{\mathrm{R}}^{\mathrm{R}}>\mathrm{N}-\mathrm{CH}_{2}-\mathrm{CH}_{2} \mathrm{C} \ll_{\mathrm{N}}^{\mathrm{O}}<_{\mathrm{R}}^{\mathrm{R}}$

$\begin{array}{lccc} & \text { 沸点 }\left({ }^{\circ} \mathrm{C} / \mathrm{mmHg}\right) & \text { 融点 }\left({ }^{\circ} \mathrm{C}\right) & \text { 收率 (\%) } \\ \mathrm{R}=\mathrm{C}_{2} \mathrm{H}_{5^{-}} & 103 \sim 106 / 6 & - & 40.0 \\ \mathrm{R}=\mathrm{O}_{\mathrm{N}}^{\mathrm{N}} & 187 \sim 189 / 7.5 & 89 \sim 93 & 57.9 \\ \mathrm{R}=\left\langle\mathrm{N}^{-}\right. & 148 \sim 155 / 7 & 37 \sim 42 & 77.4\end{array}$

（4）安息香酸アミドと重再硫酸ソータととのホルムアルデヒド による連結化合物における交換連結反応

安息香酸の $\mathrm{N}$ ースルホメチル化物は次のよ5にして合成した。 すなわちホルムアルデヒドの重垔硫酸ソーダ付加物 $80 \mathrm{~g}$ と安息 香酸アミド $36 \mathrm{~g}$ とを混ぜ，蒸発皿中で捏和，かきまぜながら 180 $190^{\circ} \mathrm{C}$ に加熱する。この生成物を少量の熱水から再結晶,
アルコールから再結晶をくり返して $37.5 \mathrm{~g}$ の目的物をえた。

N 5.60\%（計算值 5.91），Na 9.32\%（計算值 9.70）。

（a）安息香酸アミドとの反応 $1 \mathrm{~g}$ の金属ナトリウムから彆 造した $\mathrm{Naーエチラートと} 18 \mathrm{~g}$ の安息香酸アミドと $7 \mathrm{~g}$ のスル ホメチル安息香酸アミドとの㯏合物を油浴上で $190 \sim 200^{\circ} \mathrm{C} に$ 5.5 時間加熱し, 冷却後熱湯でよく洗浄してその残留物 $6.3 \mathrm{~g}$ （粗収率 84\%）をえた。これをアルコールから再結晶すると $\mathrm{mp}$ $219 \sim 219.5^{\circ} \mathrm{C}$ を示し, 他の方法で合成したメチレンビスベンズ アミドと混融して融点の降下を認めなかった。

C 70.75\% (70.80), H 5.73\% (5.55), N 10.95\% (11.00) $\mathrm{NaOH}$ を触媒としても $82 \%$ の収率で同一物をえた。

（b）フタルイミドとの反応 $1 \mathrm{~g}$ の金属ナトリウムから製造 した Na-エチラートとフタルイミド $20 \mathrm{~g}$ とスルホメチルベンズ アミド $7 \mathrm{~g}$ とを混ぜ $190 \sim 200^{\circ} \mathrm{C} に 3$ 時間加熱し, 冷却後熱水に てょく洗浄, さらに未反応フタルイミドを Pucher 7) の処方でホ ルマリン水で処理して水溶性の N-メチロールフタルイミドとし て除去し，最後に不溶白色残留物 $4.2 \mathrm{~g}$ （粗収率 $51 \%$ ）をえた。 これをアルコールから 2 回, ベンゼンから 4 回再結晶をくり返し て行い，mp 183 $184^{\circ} \mathrm{C}$ の目的物をえた。これは文献記載 ${ }^{8)} の$ $\mathrm{C}_{8} \mathrm{H}_{5} \mathrm{CONH} \mathrm{CH}-\mathrm{N}<$ の融点とよく一致し, その分析值も 次のと扣りでよく計算值（カッコ内）と一致する。

C $68.24 \%$ (68.55), H 4.49\% (4.32), N 9.72\% (9.99)

(c) カルパゾールとの反空 前項と同様に $1 \mathrm{~g}$ の金属ナトリ ウムから製造した $\mathrm{Na-エチラートとカルバゾール} 22 \mathrm{~g}$, 安息香 酸の $\mathrm{N}$ ースルホメチルアミド $9 \mathrm{~g}$ との混合物を $185 \sim 205^{\circ} \mathrm{C}$ に 3 時間かきまぜながら反応させ，冷却後熱水でよく洗净し，さらに 未反応カルパゾールを除去するためにホルマリン水と重亚硫酸》 一ダで水溶性の N-メチロールカルパジールとし, その残留物と して $5.6 \mathrm{~g}$ (粗収率 49\%) の目的物をえた。これをアルコールか

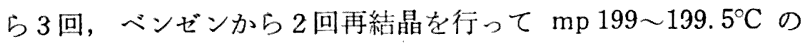
物質をえ，その分析值は次のようで，安息香酸アミドとカルバジ ールとがホルムアルデヒドで連結された化合物としての計算值

C $79.70 \%$ (79.98), H 5.56\% (5.37), N 9.58\% (9.33)

（カッコ内）とよく一致する。

\section{総括}

以上アミンとアルコールとのホルムアルデヒドによる連結化合 物 $\left(\mathrm{R}_{2}\right) \mathrm{N}-\mathrm{CH}_{2}-\mathrm{OR}^{\prime}$ がスチレン，エチレンオキシド，ケテンと 新しい種の化学反応（一種の交換連結反応）を起すことを確かめ た。また Nースルホメチル安息香酸アミドと安息香酸,フタルイ ミド，カルパゾールとの間の交換連結反応を研究した。

7) G. W. Pucher, J. Am. Chem. Soc. 44, 820 (1922).

8) R. P. Linstead, J. Chem. Soc. 1951, 2854. 